\title{
The Effect of Social Media on Consumer Behavior: An Application on University Students in Turkey
}

\author{
Yakup Durmaz and Elif Uysal Alagöz
}

\begin{abstract}
The main purpose of this research is to show how social media influence the consumption behaviors of university students in Turkey. This research is designed as a "screening model". Screening models are research approaches that aim to describe the past or present as it exists. It is tried to define an event, individual or object under investigation as it is and, as if it is within its own conditions. No attempt is made to change or influence them in anyway. Social media has provided new opportunities for consumers to socialize online. Consumers have thus made social media a part of their daily lives. The increasing number of social media users worldwide is one of the most important indicators of this. The general status of the Internet allows individuals to use social media from e-mail to Twitter and Facebook, and interact without the need for physical meetings. The purpose of this research is to assess the effect of social media on consumer behaviors of university students, who are themselves consumers and social media users. In conclusion, the aim is to investigate the effect of using social networks on the pre-purchase consumer behavior of university students in social media.
\end{abstract}

Index Terms - Social media, consumer behavior, dimensions of social media, social media tools.

\section{INTRODUCTION}

Consumers have made social media a part of their daily lives. The increasing number of social media users worldwide is one of the most important indicators of this. Social media marketing is a new marketing approach based on a process in which the consumer has a high level of right to speech, people can easily speak with each other, and the reaction of the opponents can be determined and acted upon. Social media is an environment where businesses can easily meet with customers and potential consumers. The ability of people to use the internet and the web tools in general, thanks to today's technology, also makes it easier for businesses to undertake their promotion efforts. Social media has become an important tool that businesses can use to build brand loyalty. Erdoğmuş and Çiçek reached the conclusion that it would be beneficial for businesses that want to establish brand loyalty to consumers to be involved in social media in many platforms and to reach social media users with different applications [10].

Published on May 29, 2019.

Yakup Durmaz, Hasan Kalyoncu University, Iktisadi Idari ve Sosyal Bilimler Fakulty, Havalimanı Yolu 8. Km. Sahinbey, Gaziantep, 27014 TURKEY (e-mail: yakup.durmaz@hku.edu.tr).

Elif Uysal Alagöz, Hasan Kalyoncu University, Iktisadi Idari ve Sosyal (email: elifuysalalagoz@ gmail.com).
When the applications of brands that use social media well and their communication with consumers are examined, it is seen that they use many social media in many ways such as finding solutions to consumer complaints, product promotion, campaign announcements, special applications, related link publishing and product usage information. Social media can be influential in many areas of business because of the effectiveness of channels and the freedom of message content. As a means of communication, social media needs to be considered and evaluated as a new element within the promotion mix [16].

\section{A. Social Media Concept and Its Dimensions}

We are witnessing similar naming of the developments in the communication process, corresponding to the modernization process and the later definitions of society. In contrast to media such as radio, television and newspapers, which are called "old media" or "mass media", media such as the internet and mobile phone, which are increasingly active today, are called 'new media' / 'social media' or roughly ' 'Refers to the structural transformation of the living process [3].

Technological developments have also been reflected in communication channels and have created a new media environment that allows people to share and discuss. This virtual environment, called social media, is important not only because it is user-based, but also because it brings people together and increases the interaction between them [24].

The main features of social media can be sorted as participation, openness, speech, society, connection, access and accessibility, up-to-dateness, permanence, etc. [20]

Social media is a concept that has dimensions such as media, user and technology. Assessing social media with just one dimension will be incomplete and inaccurate. Social media is made up of three dimensions:

\section{a. Media Dimension of Social Media}

The media concept is important for businesses. The marketing approach that sees media tools as a medium for marketing communication has increased the importance of these tools day by day. In this context, the media can be seen as all of the means of disseminating information, enabling a 
message to reach a group as much as a means of expression [19].

\section{b. User Dimension of Social Media}

User-created media, also used as consumer-driven content is defined as the new type of online information source that users create, become members of, disseminate and use for the purpose of obtaining information about products, brands, services, people or interests and informing other users [13]. It has three characteristics and these are publishing obligation, creative effort, and being independent of professional routines and practices [21].

\section{c. Technological Dimension of Social Media}

The initial aim of web sites established in the first period is only to exist in this new platform. In this way, users on this platform will get the chance to view the information they want, when they want it. Rapid developments in technology and the fact that people start to spend more time on the internet as a user has forced the Web to shift to a social direction [17].

\section{B. Social Media Tools}

Social media tools differ from each other in some aspects. Social media tools with a basic understanding of sharing userbased content; Blogs, media sharing sites, and social networks. The main social media sites can be summarized as follows:

Social media tools, which have a basic understanding of sharing user-based content, can emerge as sites with different features such as blogs, media sharing sites, and social networks. The main social media sites can be summarized as follows:
Blog: Blogs are defined as tools that direct users social sharing and engagement. Blog is a kind of content management system that allows anyone to easily publish short articles called messages.

Microblog: This is a customized blog type. Microblogging is a website format for publishing short updates using online tools such as Twitter, Plurk, and Jaiku, generally with 140 characters or less [12].

Media Sharing Sites: Media sharing sites allow users to create and upload multimedia content called user-based content [26].

Twitter: It was founded in 2006 and was first used for intracompany instant messaging and connectivity [6].

Wikies: Wikies are defined as collaborative websites that allow users to add and edit content [10].Podcasting: Podcasting publishes audio and video files on the Internet and broadcast a "push" if the user has the multimedia hardware application [18].

Photo, Music, Video Sharing Sites: As a result of the fact that almost everyone has electronic devices such as computers, digital cameras and photographic machines, internet users have the ability to accumulate plenty of photos, videos and similar content. Internet users have been able to share photos and videos that they have produced with their own content sharing sites or within other web sites, and have been able to vote, comment, and follow other photos and videos.

Facebook: It is a member-based internet community that allows users to upload various profile information like username, photo, send public or private online messages, and communicate with other users in the system in several ways like online photo sharing [5].

Table 1. Main social media practices according to social media goals [4]

\begin{tabular}{|c|c|c|c|}
\hline SOCIAL MEDIA PLATFORM & BRAND RECOGNITION & BRAND LOYALTY & $\begin{array}{lcc}\text { WORD } & \text { OF } & \text { MOUTH } \\
\text { COMMUNICATION WOM) }\end{array}$ \\
\hline Blogs & $\begin{array}{l}\text { Number of unique visits } \\
\text { Number of unique return visits } \\
\text { Number of markings } \\
\text { Search order }\end{array}$ & $\begin{array}{l}\text { Number of members } \\
\text { Number of comment } \\
\text { The amount of content created } \\
\text { Average stay on site } \\
\text { Number of return to votes, } \\
\text { contest or questionnaire }\end{array}$ & $\begin{array}{l}\text { Number of likes } \\
\text { Reference number from other media } \\
\text { sender } \\
\text { Reblog number }\end{array}$ \\
\hline $\begin{array}{l}\text { Microblogging } \\
\text { Twitter }\end{array}$ & $\begin{array}{l}\text { Number of tweets about the brand } \\
\text { Tweet value }(-,+) \text { Number of followers }\end{array}$ & $\begin{array}{l}\text { Number of followers@ } \\
\text { number of responses }\end{array}$ & Number of tweet return \\
\hline $\begin{array}{l}\text { Customize Your Own } \\
\text { Nike ID }\end{array}$ & Number of visits & Number of creation trials & $\begin{array}{l}\text { Reference number displayed in another } \\
\text { media }\end{array}$ \\
\hline Social Marking & Number of being tagged & Number of followers & Number of additional tagger \\
\hline $\begin{array}{l}\text { Forums, } \\
\text { Discussion boards Google Groups }\end{array}$ & $\begin{array}{l}\text { Number of pages viewed } \\
\text { Number of visits } \\
\text { Value of submitted content (+/_) }\end{array}$ & $\begin{array}{l}\text { Related title, number of topics } \\
\text { Number of individual } \\
\text { responses } \\
\text { Number of sign ups }\end{array}$ & $\begin{array}{l}\text { Being tagged on social marking } \\
\text { Excerpt from other sites } \\
\text { Linked links } \\
\text { Link to other sites }\end{array}$ \\
\hline Product Evaluation (Amazon) & $\begin{array}{l}\text { Number of reviews submitted } \\
\text { Value of criticism }(-/+) \\
\text { The number of responses to criticism by } \\
\text { other users and the value }(-/+) \\
\text { Request list number } \\
\text { Number of adding products to the user's list }\end{array}$ & $\begin{array}{l}\text { The length of the criticism The } \\
\text { relevance of criticism } \\
\text { Ratings of other users' liking } \\
\text { criticism }(-/+) \\
\text { Number of request list } \\
\text { Total number of critical points } \\
\text { entered } \\
\text { Average critics scores }\end{array}$ & $\begin{array}{l}\text { Number of reviews submitted } \\
\text { Value of criticsm } \\
\text { Number of site visits } \\
\text { The number and value of other users' } \\
\text { responses to criticism }(-/+)\end{array}$ \\
\hline Social Networks Facebook & $\begin{array}{l}\text { Number of members and fans } \\
\text { Placement number of application } \\
\text { Number of effects } \\
\text { Number of signals } \\
\text { Number and value of criticism / point }(-/+)\end{array}$ & $\begin{array}{l}\text { Number of comment } \\
\text { Number of active users } \\
\text { Number of likes } \\
\text { Number of content created by } \\
\text { users } \\
\text { Measurements of application } \\
\text { usage }\end{array}$ & $\begin{array}{l}\text { Frequency of viewing your friends in } \\
\text { the time tunnel } \\
\text { Number of wall posts } \\
\text { Number of shares and submissions } \\
\text { Number of responses to friend } \\
\text { suggestions }\end{array}$ \\
\hline
\end{tabular}




\begin{tabular}{|l|l|l|l|}
\hline & & $\begin{array}{l}\text { Activity rate (how often } \\
\text { members update pages) }\end{array}$ & \\
\hline $\begin{array}{l}\text { Video and Photo Sharing } \\
\text { YouTube, Flickr }\end{array}$ & $\begin{array}{l}\text { Video / photo views } \\
\text { Video / photo rating value }(-/+)\end{array}$ & $\begin{array}{l}\text { Number of responses } \\
\text { Number of pageview } \\
\text { Number of criticism } \\
\text { Number of members }\end{array}$ \\
\hline
\end{tabular}

In a social media environment, marketing managers have the opportunity to develop social media programs that will deal with brand awareness, brand loyalty and word of mouth communication. Hoffman and Fodor proposed various measurement criteria in Table 1 for different social media platforms for these purposes [4].

\section{Consumer and Consumer Behavior Concept}

According to Article 3 of the Consumer Protection Law, the consumer is a "real and legal person who acquires, uses or makes use of a good or service for commercial or nonprofessional purposes" [5]. According to McNeal, the consumer is the person who plays a role in any of the prepurchase, purchase and postpurchase processes [23].

Consumer behaviors are the ones that include the decisionmaking process, dispositions, searching, selecting, purchasing, using and disposing of products and services that will satisfy the consumer's wishes and needs. Consumer behavior, when taken into account with the most general meaning, involves the emotional, mental and behavioral activities of the consumer throughout the process of purchasing, using and disposing of products, services and ideas in order to satisfy needs and desires [15]. The reasons for consumption are based on both the product's color, form, packaging, etc. and the consumer's social position, conscious or unconscious passion. For this reason, the producer can direct the consumer in the direction he intends [14].

\section{Consumer Behavior in Social Media}

Social media changes the decision-making process in consumer purchase behavior and adds a new factor that businesses cannot control to this process [7]. In social media, consumers both influence other users and are influenced by other users. In this sense, it is possible to say that social media has an impact on consumer behavior. Durukan, Bozac1 and Hamsioğlu's study on consumption behaviors in social media tools has divided these behaviors into three. These are [17];

- Behaviors that affect consumption (positive word of mouth communication, negative oral word of mouth communication, opinion leadership)

- Behaviors influenced by others about consumption (searching for information about products, researching friends' thoughts)

- Use social media as a communication tool for consumers to decide when to decide a purchase and to report complaints, dissatisfaction and satisfaction with companies.

In this context, demographic, psychological, sociocultural and situational factors affecting consumer behaviors are taken into consideration together with their effects on social media.
1. Demographic Factors: Consumers with different age, gender, educational background, geographical location, occupation or income may have similar or different purchasing or social media usage behaviors according to these characteristics [17]..

2. Psychological Factors: Variables such as learning, motivation, perception, personality and attitude are the sublayers of the psychological factor [9]. Consumers in social media care about those contents that appeal to them in a personal or emotional sense. In this sense, it can be said that the content in the social media has a psychological dimension. Psychological reactions of social media users to wards content are acknowledging, paying attention, appreciating, trusting, praising and being apart of a group [22].

3. Socio-Cultural Factors: Social and cultural factors are the factors that affect consumer behavior. This topic, which is considered as social or socio-cultural factors in the literature, is handled together with concepts such as family, groups, advisory group, social class, culture [22]. In social media tools, the communication that occurs as a result of users talking to other users directly and indirectly affects them. Indirect effect is manifested by contributing to product development, while direct effect occurs when users deciding to purchase [25].

4. Situational Factors: Situational factors are the factors related to how consumers will behave in different situations. Situational factors can be classified into five subgroups as physical effects, social environment, time dimension, goal dimension, emotional state, facilitating elements [17].

\section{Methodology}

\section{A. Purpose and Scope of the Study}

The main purpose of this research is to show how social media influence the consumption behaviors of university students in Turkey. The other purpose of the research are to determine the frequency with which social media is used by university students and to assess the extent to which social media instruments generally influence participants' consumer behavior before and after purchase. It is expected that the results of the survey will provide marketing professionals, social media users and businesses with benefits in terms of consumer behavior in social media. The scope of the researcher is to determine the usage and the degree of influence of consumers who use social media in Turkey.

\section{B. Model of the research}

This research is designed as a "screening model". "Screening models are research approaches that aim to describe the past or present as it exists. It is tried to define an event, individual or object under investigation as it is and, as if it is within its own conditions. No attempt is made to change or influence them in anyway " [19]. 


\section{Population and Sample}

Social media environments are online environments in which users have different demographic characteristics. Population of the study consists of students at Gaziantep University who have different demographic characteristics and use one or more social media tools and the sample consists of the students of Nizip Faculty of Education. A total of 362 university students participated in the research.

\section{Data Collection Tool}

As a data collection tool, 9 separate scales for determining social media usage levels, 2 separate scales for determining consumer behaviors, and a form for determining how much the social media tools affected purchase behavior were used together with descriptive information [17]. Expressions related to scales were used unchanged. It is seen that İşlek calculates the reliability coefficients of the scale for determining the level of social media usage in the study. The reliability coefficients calculated by İşlek are given below.

Table 2. Reliability Coefficients [17]

\begin{tabular}{lcc}
\hline Scales & Cronbach Alpha & Item Number \\
\hline Level of blog usage. & 0,86 & 4 \\
Level of microblog usage. & 5 \\
Level of Social Network usage (Facebook, Google Plus). & 10 \\
Level of Media Sharing Site usage (YouTube, Flickr, Slide share). & 0,95 \\
Level of Wiki (Wikipedia) usage. & 0,85 & 3 \\
Level of Social Marking and Labeling Site usage (StumbleUpon, Reddit). & 3 \\
Level of Online Communities usage (Forums, Dictionaries). & 3 \\
Level of Podcast usage. & 0,76 \\
Level of Virtual Worlds usage (Knight Online, WOW, Second Life). & 3 \\
\hline
\end{tabular}

\section{E. Statistical Analysis of Data}

The data obtained in the study were analyzed using SPSS (Statistical Package for Social Sciences) for Windows 22.0 program. Number, percentage, mean, standard deviation were used as descriptive statistical methods in the evaluation of the data.

Scores of scale dimensions are evaluated between 1 and 5 . For the purpose of calculating the distribution range, Distribution range $=$ Maximum value - Minimum value / Number of degrees formula is used. This range is 4 points wide. This width was divided into five equal widths, ranging from between 1.00 - 1.79 "very low", between $1.80-2.59$ "low", between 2.60 - 3.39 "medium", between 3.40-4.19 "high", between 4.20 - 5 " very high".

The t-test was used to compare quantitative continuous data between two independent groups, and One way Anova test was used to compare quantitative continuous data between two independent groups. The Scheffe test was used as a complementary post-hoc analysis to determine the differences after the Anova test.
Among the continuous variables of the study, Pearson correlation and regression analysis were applied. Correlation analysis is applied to determine the strength (degree) and direction of the linear relationship between continuous variables. To determine the causality relation between the continuous variables of the study, regression analysis is applied to estimate the value of the dependent variable which is hardly obtained by using the independent variables (http://www.istatistikanaliz.com/regression_analizi.asp). The findings were evaluated in $95 \%$ confidence interval and $5 \%$ significance level.

\section{F. Findings and Comments}

In this section, the findings obtained from the analysis of the data collected through the scales of the students participating in the research are presented for the solution of the research problem. Explanations and interpretations were made based on the findings obtained.

Table 3. Distribution of Descriptive Characteristics of Students

\begin{tabular}{|l|l|c|c|}
\hline \multicolumn{1}{|c|}{ Tables } & \multicolumn{1}{|c|}{ Groups } & Frequency(n) & Percentage (\%) \\
\hline \multirow{5}{*}{ Social media usage per week } & $0-5$ Hours & 110 & $\mathbf{3 0 , 4}$ \\
\cline { 2 - 4 } & $6-10$ Hours & 80 & 22,1 \\
\cline { 2 - 4 } & $11-15$ Hours & 45 & 12,4 \\
\cline { 2 - 4 } & $16-20$ Hours & 54 & 6,9 \\
\cline { 2 - 4 } & $21-25$ Hours & 24 & 4,1 \\
\cline { 2 - 4 } & $26-30$ Hours & 34 & 9,4 \\
\cline { 2 - 4 } & Over 30 Hours & 362 & 100,0 \\
\cline { 2 - 4 } & Total & 13 & 3,6 \\
\hline \multirow{5}{*}{ Frequent Tools to Social Media } & Personal Computer & 24 & 2,8 \\
\cline { 2 - 4 } & Institutional Computer & & 6,6 \\
\cline { 2 - 4 } & Tablet & & \\
\end{tabular}




\begin{tabular}{|c|c|c|c|}
\hline & Smart Phone & 315 & 87,0 \\
\hline & Total & 362 & 100,0 \\
\hline \multirow[t]{4}{*}{ Age } & $18-20$ & 175 & 48,3 \\
\hline & $20-22$ & 131 & 36,2 \\
\hline & Over 22 & 56 & 15,5 \\
\hline & Total & 362 & 100,0 \\
\hline \multirow[t]{3}{*}{ Gender } & Female & 258 & 71,3 \\
\hline & Male & 104 & 28,7 \\
\hline & Total & 362 & 100,0 \\
\hline
\end{tabular}

According to the duration of social media usage in a week, $110(30,4 \%)$ of the participants 0-5 hours (İşlek, 2012), 80 $(22,1 \%)$ 6-10 hours, 45 ) 11-15 hours, 54 (14,9\%) 16-20 hours, $24(6,6 \%)$ 21-25 hours, 15 (4,1\%) 26-30 hours, 34 $(9,4 \%)$ are distributed over 30 hours. According to the tool variable frequently used for social media, $13(3,6 \%)$ participants personal computers (İşlek, 2012), 10 (2,8\%) institutional computers, $24(6,6 \%)$ tablets, $315(87,0 \%)$ are distributed as smartphones. According to the age variable, $175(48,3 \%)$ students were $18-20,131(36,2 \%)$ were $20-22$, $56(15,5 \%)$ were over 22 years of age and $258(71,3 \%)$ were female and $104(28,7 \%)$ were male.

Table 4 shows the distributions of the answers given by the students who participated in the research about the Consumer Behavior in Social Media.

Table 4. Distribution of Answers Given by Students on Consumer Behavior in Social Media

\begin{tabular}{|c|c|c|c|c|c|c|c|c|c|c|c|c|}
\hline & \multicolumn{2}{|c|}{ 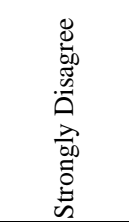 } & \multicolumn{2}{|c|}{ 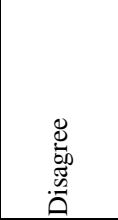 } & \multicolumn{2}{|c|}{ 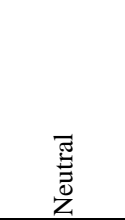 } & \multicolumn{2}{|c|}{ 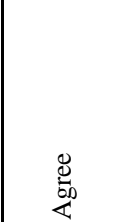 } & \multicolumn{2}{|c|}{ 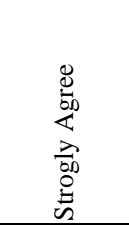 } & \multirow[b]{2}{*}{ Ort } & \multirow[t]{2}{*}{\begin{tabular}{|} 
\\
Ss \\
\end{tabular}} \\
\hline & f & $\%$ & f & $\%$ & f & $\%$ & f & $\%$ & f & $\%$ & & \\
\hline I Make a Research Related to the Product Service in Social Media Before Purchasing It & 65 & 18,0 & 45 & 12,4 & 76 & 21,0 & 72 & 19,9 & 104 & 28,7 & 3,290 & 1,453 \\
\hline $\begin{array}{l}\text { I Make Research About Consumer-Generated Information Related to the Product to be } \\
\text { Purchased in Social Media }\end{array}$ & 83 & 22,9 & 83 & 22,9 & 107 & 29,6 & 53 & 14,6 & 36 & 9,9 & 2,658 & 1,256 \\
\hline $\begin{array}{l}\text { I Make Research About Seller-Generated Information Related to the Product to be } \\
\text { Purchased in Social Media }\end{array}$ & 129 & 35,6 & 94 & 26,0 & 82 & 22,7 & 34 & 9,4 & 23 & 6,4 & 2,249 & 1,214 \\
\hline $\begin{array}{l}\text { I Make Research About Recommendations Made by People I Know Before Related to } \\
\text { the Service Product I will purchase in Social Media }\end{array}$ & 82 & 22,7 & 61 & 16,9 & 87 & 24,0 & 68 & 18,8 & 64 & 17,7 & 2,920 & 1,403 \\
\hline \begin{tabular}{|l|} 
I Make Research About Recommendations Made by Users Who Are Popular in Social \\
Media (follower, friend) Related to the Service Product I will purchase in Social Media
\end{tabular} & 138 & 38,1 & 77 & 21,3 & 72 & 19,9 & 36 & 9,9 & 39 & 10,8 & 2,340 & 1,355 \\
\hline I Wait for a Company Brand in Social Media to Communicate with Me & 118 & 32,6 & 69 & 19,1 & 81 & 22,4 & 46 & 12,7 & 48 & 13,3 & 2,550 & 1,398 \\
\hline I Participate in Campaigns Organized by Companies in Social Media & 185 & 51,1 & 65 & 18,0 & 53 & 14,6 & 24 & 6,6 & 35 & 9,7 & 2,058 & 1,340 \\
\hline If I am Satisfied with the Product Service I Purchase, I Share This in Social Media & 209 & 57,7 & 57 & 15,7 & 52 & 14,4 & 25 & 6,9 & 19 & 5,2 & 1,862 & 1,206 \\
\hline $\begin{array}{l}\text { If I am Satisfied with the Product Service I Purchase, I Share This in the Company } \\
\text { Pages in Social Media }\end{array}$ & 230 & 63,5 & 57 & 15,7 & 40 & 11,0 & 17 & 4,7 & 18 & 5,0 & 1,718 & 1,143 \\
\hline If I am not Satisfied with the Product Service I Purchase, I Share This in Social Media & 193 & 53,3 & 66 & 18,2 & 53 & 14,6 & 21 & 5,8 & 29 & 8,0 & 1,970 & 1,279 \\
\hline $\begin{array}{l}\text { If If am not Satisfied with the Product Service I Purchase, I Share This in the } \\
\text { Company Pages in Social Media }\end{array}$ & 184 & 50,8 & 67 & 18,5 & 58 & 16,0 & 27 & 7,5 & 26 & 7,2 & 2,017 & 1,272 \\
\hline $\begin{array}{l}\text { If I I am Satisfied with the Product Service I Purchase, I Recommend Other Users to } \\
\text { Purchase It in Social Media }\end{array}$ & 177 & 48,9 & 67 & 18,5 & 67 & 18,5 & 28 & 7,7 & 23 & 6,4 & 2,041 & 1,248 \\
\hline $\begin{array}{l}\text { I If I am not Satisfied with the Product Service I Purchase, I Recommend Other Users } \\
\text { Not to Purchase in Social Media }\end{array}$ & 157 & 43,4 & 67 & 18,5 & 80 & 22,1 & 29 & 8,0 & 29 & 8,0 & 2,188 & 1,291 \\
\hline
\end{tabular}

When the responses of students participating in the survey on the Consumer Behavior in Social Media are examined;

$18,0 \%(n=65)$ of the students answered as strongly disagree for the statement "I Make a Research Related to the Product Service in Social Media Before Purchase It", 12,4\% $(\mathrm{n}=45)$ disagree, 21,0\% $(\mathrm{n}=76)$ neutral, 19,9\% $(\mathrm{n}=72)$ agree and $28,7 \%(\mathrm{n}=104)$ strongly agree. It has been determined that the students' agreement level with the statement "I Make a Research Related to the Product Service in Social Media Before Purchasing It" was medium (3,290 \pm 1,453).

DOI: http://dx.doi.org/10.24018/ejbmr.2019.4.2.39
It was seen that $22,9 \%(n=83)$ of the students answered as strongly disagree for the item "I Make Research About Consumer-Generated Information Related to the Product to be Purchased in Social Media", 22,9\% $(\mathrm{n}=83)$ disagree, 29,6 $(\mathrm{n}=107)$ neutral, 14,6\% $(\mathrm{n}=53)$ agree, and 9,9\% $(\mathrm{n}=36)$ strongly agree. It was determined that the students' agreement level with the statement "I Make Research About ConsumerGenerated Information Related to the Product to be Purchased in Social Media" was medium $(2,658 \pm 1,256)$

For the item "I Make Research About Seller-Generated Information Related to the Product to be Purchased in Social 
Media", 35,6\% $(\mathrm{n}=129)$ of the students answered as strongly disagree, $26,0 \%(\mathrm{n}=94)$ disagree and $22,7 \%(\mathrm{n}=82)$ neutral, $9,4 \%(n=34)$ agree, and 6,4\% $(n=23)$ strongly agree. The students' agreement level with the statement "I Make Research About Seller-Generated Information Related to the Product to be Purchased in Social Media" was found to be low $(2,249 \pm 1,214)$.

$22,7 \%(\mathrm{n}=82)$ of the students answered as strongly disagree for the item "I Make Research About Recommendations Made by People I Know Before Related to the Service Product I will purchase in Social Media", $16,9 \%(\mathrm{n}=61)$ disagree, $24,9 \%(\mathrm{n}=87)$ neutral, $18,8 \%(\mathrm{n}=$ $68)$ agree and $17,7 \%(n=64)$ strongly agree. The students' agreement level with the statement "I Make Research About Recommendations Made by People I Know Before Related to the Service Product I will purchase in Social Media" was found to be medium $(2,920 \pm 1,403)$.

For the item "I Make Research About Recommendations Made by Users Who Are Popular in Social Media (follower, friend) Related to the Service Product I will purchase in Social Media", 38,1\% $(\mathrm{n}=138)$ of the students answered as strongly disagree, $21,3 \%(\mathrm{n}=77)$ disagree, $19,9 \%(\mathrm{n}=72)$ neutral, 9,9\% $(\mathrm{n}=36)$ agree and $10,8 \%(\mathrm{n}=39)$ strongly agree. It was determined that the students' agreement level wit the statement "I Make Research About Recommendations Made by Users Who Are Popular in Social Media (follower, friend) Related to the Service Product I will purchase in Social Media" was low $(2,340 \pm 1,355)$.

It was seen that $32,6 \%(n=118)$ of the students answered as strongly disagree for the item "I Wait for a Company Brand in Social Media to Communicate with Me", 19,1\% (n=69) disagree, $22,4 \%(n=81)$ neutral, $12,7 \%(n=46)$ agree and $13,3 \%(\mathrm{n}=48)$ strongly agree. The students agreement level with the statement "I Wait for a Company Brand in Social Media to Communicate with Me" was found to be low (2,550 $\pm 1,398$ ).

For the item "I Participate in Campaigns Organized by Companies in Social Media", 51,1\% $(n=185)$ of the students answered as strongly disagree, $18,0 \%(\mathrm{n}=65)$ disagree, $14,6 \%(\mathrm{n}=53)$ neutral, 6,6\% $(\mathrm{n}=24)$ agree and 9,7\% $(\mathrm{n}=$ 35) strongly agree. The students' agreement level with the statement "I Participate in Campaigns Organized by Companies in Social Media" was found to be low (2,058 \pm 1,340).

$57,7 \%(\mathrm{n}=209)$ of the students answered as strongly disagree for the item "If I am Satisfied with the Product Service I Purchase, I Share This in Social Media", 15,7\% (n $=57)$ disagree, $14,4 \%(n=52)$ neutral, 6,9\% $(n=25)$ agree, and $5,2 \%(\mathrm{n}=19$ strongly agree. It was determined that the students' agreement level with the statement "If I am
Satisfied with the Product Service I Purchase, I Share This in Social Media" was low $(1.862 \pm 1.206)$.

It was seen that $63,5 \%(n=230)$ of the students answered as strongly disagree for the item "If I am Satisfied with the Product Service I Purchase, I Share This in the Company Pages in Social Media", 15,7\% $(\mathrm{n}=57)$ disagree, $11,0 \%(\mathrm{n}=$ $40)$ neutral, $4,7 \%(n=17)$ agree and $5,0 \%(n=18)$ strongly agree. The students' agreement level with the statement "If I am Satisfied with the Product Service I Purchase, I Share This in the Company Pages in Social Media" was found to be very low $(1,718 \pm 1,143)$.

For the item "If I am not Satisfied with the Product Service I Purchase, I Share This in Social Media", 53,3\% $(\mathrm{n}=193)$ of the students answered as strongly disagree, $18,2 \%(\mathrm{n}=66)$ disagree, $14,6 \%(\mathrm{n}=53)$ neutral, $5,8 \%(\mathrm{n}=21)$ agree and $8,0 \%(\mathrm{n}=29)$ strongly agree. It was determined that the students' agreement level with the statement "If I am not Satisfied with the Product Service I Purchase, I Share This in Social Media" was low $(1,970 \pm 1,279)$.

$50,8 \%(\mathrm{n}=184)$ of the students answered as strongly disagree for the item item "If I am not Satisfied with the Product Service I Purchase, I Share This in the Company Pages in Social Media", 18,5\% $(\mathrm{n}=67)$ disagree, $16,0 \%(\mathrm{n}=$ 58) neutral, $7,5 \%(n=27)$ agree and 7,2\% $(n=26)$ strongly agree. The students' agreement level with the statement "If I am not Satisfied with the Product Service I Purchase, I Share This in the Company Pages in Social Media" was found to be low $(2,017 \pm 1,272)$.

$48,9 \%$ ( $n=177)$ of the students answered as strongly disagree for the item "I If I am Satisfied with the Product Service I Purchase, I Recommend Other Users to Purchase It in Social Media", 18,5\% $(n=67)$ disagree, $18,5 \%(n=67)$ neutral, 7,7\% ( $\mathrm{n}=28)$ agree and 6,4\% $(\mathrm{n}=23)$ strongly agree. It was seen that the students' agreement level with the statement "I If I am Satisfied with the Product Service I Purchase, I Recommend Other Users to Purchase It in Social Media" was low $(2,041 \pm 1,248)$.

For the item "I If I am not Satisfied with the Product Service I Purchase, I Recommend Other Users Not to Purchase in Social Media", 43,4\% $(n=157)$ of the students answered as strongly disagree, $18,5 \%(\mathrm{n}=67)$ disagree, $22,1 \%(\mathrm{n}=80)$ neutral, 8,0\% ( $\mathrm{n}=29)$ agree, and 8,0\% ( $\mathrm{n}=29)$ strongly agree. The students' agreement level with the statement "I If I am not Satisfied with the Product Service I Purchase, I Recommend Other Users Not to Purchase in Social Media" was found to be low $(2,188 \pm 1,291)$.

Table 5 shows the distributions of the answers given by the students who participated in the research about how much social media tools affect the purchase decision.

Table 5. Distribution of Answers Given by Students on How Much Social Media Tools Affect Purchase decision

\begin{tabular}{|c|c|c|c|c|c|c|c|c|c|c|c|c|}
\hline & \multicolumn{2}{|c|}{ Never Affects } & \multicolumn{2}{|c|}{ Partly Affects } & \multicolumn{2}{|c|}{ Affects } & \multicolumn{2}{|c|}{ Affects Much } & \multicolumn{2}{|c|}{ Affects Very Much } & \multirow[b]{2}{*}{ Avr. } & \multirow[b]{2}{*}{ SD } \\
\hline & $\mathrm{f}$ & $\%$ & $\mathrm{f}$ & $\%$ & $\mathrm{f}$ & $\%$ & $\mathrm{~F}$ & $\%$ & $\mathrm{f}$ & $\%$ & & \\
\hline Blog & 245 & 67,7 & 56 & 15,5 & 37 & 10,2 & 23 & 6,4 & 1 & 0,3 & 1,561 & 0,931 \\
\hline Microblog (twitter) & 222 & 61,3 & 54 & 14,9 & 46 & 12,7 & 38 & 10,5 & 2 & 0,6 & 1,740 & 1,070 \\
\hline Social Network (facebook, Google Plus) & 125 & 34,5 & 65 & 18,0 & 96 & 26,5 & 70 & 19,3 & 6 & 1,7 & 2,356 & 1,187 \\
\hline Media Sharing Sites (youtube, Flickr, Slideshare) & 140 & 38,7 & 64 & 17,7 & 83 & 22,9 & 71 & 19,6 & 4 & 1,1 & 2,268 & 1,197 \\
\hline Wikies (wikipedia) & 194 & 53,6 & 57 & 15,7 & 61 & 16,9 & 45 & 12,4 & 5 & 1,4 & 1,923 & 1,151 \\
\hline Social Marking and Labeling Sites (stumbleupon, Reddit) & 251 & 69,3 & 52 & 14,4 & 38 & 10,5 & 19 & 5,2 & 2 & 0,6 & 1,533 & 0,918 \\
\hline Online Communities (forums, dictionaries) & 189 & 52,2 & 72 & 19,9 & 72 & 19,9 & 25 & 6,9 & 4 & 1,1 & 1,848 & 1,038 \\
\hline
\end{tabular}




\begin{tabular}{|c|c|c|c|c|c|c|c|c|c|c|c|c|}
\hline Podcast & 263 & 72,7 & 50 & 13,8 & 31 & 8,6 & 15 & 4,1 & 3 & 0,8 & 1,467 & 0,878 \\
\hline Virtual Worlds (knight Online, Wow, Second Life) & 258 & 71,3 & 55 & 15,2 & 31 & 8,6 & 16 & 4,4 & 2 & 0,6 & 1,478 & 0,869 \\
\hline
\end{tabular}

When the answers given by the students who participated in the research about how much social media tools affect the purchase decision are examined;

It was found that $67,7 \%(n=245)$ of the students answered as never affects for the item "Blog", $61,3 \%(n=222)$ of the students answered as never affects for the item "Microblog (twitter)", 34,5\% $(\mathrm{n}=125)$ of the students answered as never affects for the item "Social Network (facebook, Google Plus)", $18,0 \%(\mathrm{n}=65)$ partly affects, $26,5 \%(\mathrm{n}=96)$ affects, $19,3 \%(\mathrm{n}=70)$ affects much, and $1,7 \%(\mathrm{n}=6)$ affects very much. It was determined that the students' agreement level with the item "Social Network (facebook, Google Plus)" was low $(2,356 \pm 1,187)$. It was found that $38,7 \%(n=140)$ of the students answered as never affects for the item "Media Sharing Sites (youtube, Flickr, Slideshare)", 17,7\% (n=64) partly affects, $22,9 \%(\mathrm{n}=83)$ affects, $19,6 \%(\mathrm{n}=71)$ affects much, and $1,1 \%(n=4)$ affects very much. It was determined that the students' agreement level with the item "Media Sharing Sites (youtube, Flickr, Slideshare)" was low (2,268 \pm $1,197) . \% 53,6(\mathrm{n}=194)$ of the students answered as never affects for the item "Wikies (wikipedia)", 15,7\% $(n=67)$ partly affects, $16,9 \%(\mathrm{n}=61)$ affects, $12,4 \%(\mathrm{n}=45)$ affects much and $1,4 \%(n=5)$ affects very much. The students' agreement level with the item "Wikies (wikipedia)" was found to be low $(1,923 \pm 1,151)$.
It was seen that $69,3 \%(n=251)$ of the students answered as never affects for the item "Social Marking and Labeling Sites (stumbleupon, Reddit)", 14,4\% $(\mathrm{n}=52)$ partly affects, $10,5 \%(\mathrm{n}=38)$ affects, $5,2 \%(\mathrm{n}=19)$ affects much, and $0,6 \%$ $(\mathrm{n}=2)$ affects very much. The students' agreement level with the item "Social Marking and Labeling Sites (stumbleupon, Reddit)" was found to be very low $(1,533 \pm 0,918) .52 .9 \%$ (n = 189) of the students answered as never affects for the item "Online Communities (forums, dictionaries)", 19,9\% $(\mathrm{n}=72)$ partly affects, $19,9 \%(\mathrm{n}=72)$ affects, $6,9 \%(\mathrm{n}=25)$ affects much, and $1,1 \%(\mathrm{n}=4)$ affects very much. The students' agreement level with the item "Online Communities (forums, dictionaries)" was found to be low $(1,848 \pm 1,038)$. For the item "Podcast", 72,7\% $(\mathrm{n}=263)$ of the students answered as never affects, $13,8 \%(\mathrm{n}=50)$ partly affects, $8,6 \%(\mathrm{n}=31)$ affects, $4,1 \%(\mathrm{n}=15)$ affects much, and $0.8 \%(\mathrm{n}=3)$ affects very much. It was found that the students' agreement level with the item "Podcast" was found to be very low $(1,467 \pm$ $0,878) .71,3 \%(\mathrm{n}=258)$ of the students answered as never affects for the item "Virtual Worlds (knight Online, Wow, Second Life)", $15,2 \%(\mathrm{n}=55)$ partly affects, $8,6 \%(\mathrm{n}=31)$ affects, 4,4\% $(\mathrm{n}=16)$ affects much, and 0,6\% $(\mathrm{n}=2)$ affects very much. The students' agreement level with the item Virtual Worlds (knight Online, Wow, Second Life) was found to be very low $(1,478 \pm 0,869)$.

Table 6. The Impact of Social Media Usage on Consumer Behavior Before Purchase in Social Media

\begin{tabular}{|c|c|c|c|c|c|c|c|}
\hline Dependent Variable & Independent Variable & B & $\mathbf{t}$ & $\mathbf{p}$ & $\mathbf{F}$ & Model (p) & $\mathbf{R}^{2}$ \\
\hline \multirow{10}{*}{$\begin{array}{l}\text { Consumer Behavior Before Purchase In Social } \\
\text { Media }\end{array}$} & Stable & 1,084 & 7,759 & 0,000 & \multirow{10}{*}{16,797} & \multirow{10}{*}{0,000} & \multirow{10}{*}{0,283} \\
\hline & Blog Usage & $-0,008$ & $-0,118$ & 0,906 & & & \\
\hline & Microblog Usage & 0,083 & 1,627 & 0,105 & & & \\
\hline & Social Network Usage & 0,224 & 3,756 & 0,000 & & & \\
\hline & Media Sharing Site usage & 0,153 & 2,100 & 0,036 & & & \\
\hline & Wiki Usage & 0,115 & 1,867 & 0,063 & & & \\
\hline & Social Marking and Labeling Site Usage & $-0,090$ & $-1,525$ & 0,128 & & & \\
\hline & Online Communities Usage & 0,221 & 3,429 & 0,001 & & & \\
\hline & Podcast usage & $-0,052$ & $-0,849$ & 0,396 & & & \\
\hline & Virtual Worlds usage & 0,045 & 0,619 & 0,536 & & & \\
\hline
\end{tabular}

Regression analysis done with the aim of determining the cause-and-effect relationship between the usage of blog, microblog, social networking, media sharing site, wiki, social marking and labelling site, online communities, podcast, virtual worlds and consumer behavior before purchase in social media was found to be statistically significant $(\mathrm{F}=$ $16,797, \mathrm{p}=0.000<0.05$ ). The relationship (the power of explanatories) with the variables the usage of blog, microblog, social networking, media sharing site, wiki, social marking and labelling site, online communities, podcast, virtual worlds with as a determinant of consumer behavior before purchase in social media, was found to be strong $\left(\mathrm{R}^{2}=\right.$ $0,283)$. The level of social network usage by the students increases the level of consumer behavior before purchase in social media $(\beta=0,224)$. The level of media sharing sites usage by the students increases the level of consumer behavior before purchase in social media $(\beta=0,153)$. The level of online communities usage by the students increases the level of consumer behavior before purchase in social media $(\beta=0,221)$.

Table 7. The Impact of Social Media Usage on Consumer Behavior After Purchase in Social Media 


\begin{tabular}{|c|c|c|c|c|c|c|c|}
\hline $\begin{array}{c}\text { Dependent } \\
\text { Variable }\end{array}$ & \begin{tabular}{|c|}
$\begin{array}{c}\text { Independent } \\
\text { Variable }\end{array}$ \\
\end{tabular} & B & $\mathbf{t}$ & $\mathbf{p}$ & F & $\begin{array}{c}\text { Model } \\
(\mathbf{p})\end{array}$ & $\mathbf{R}^{2}$ \\
\hline \multirow{10}{*}{$\begin{array}{l}\text { Consumer } \\
\text { Behavior } \\
\text { After } \\
\text { Purchase } \\
\text { In Social } \\
\text { Media }\end{array}$} & Stable & 0,284 & 2,248 & 0,025 & \multirow{10}{*}{26,584} & \multirow{10}{*}{0,000} & \multirow{10}{*}{0,389} \\
\hline & Blog Usage & 0,060 & 1,028 & 0,305 & & & \\
\hline & $\begin{array}{l}\text { Microblog } \\
\text { Usage }\end{array}$ & 0,110 & 2,384 & 0,018 & & & \\
\hline & \begin{tabular}{|l|} 
Social \\
Network \\
Usage \\
\end{tabular} & 0,153 & 2,849 & 0,005 & & & \\
\hline & $\begin{array}{l}\text { Media Sharing } \\
\text { Site usage }\end{array}$ & 0,233 & 3,550 & 0,000 & & & \\
\hline & Wiki Usage & 0,083 & 1,490 & 0,137 & & & \\
\hline & $\begin{array}{l}\text { Social } \\
\text { Marking and } \\
\text { Labeling Site } \\
\text { Usage } \\
\end{array}$ & $\begin{array}{c}- \\
0,127\end{array}$ & $\begin{array}{c}- \\
2,391\end{array}$ & 0,017 & & & \\
\hline & \begin{tabular}{|l|} 
Online \\
Communities \\
Usage \\
\end{tabular} & 0,149 & 2,552 & 0,011 & & & \\
\hline & Podcast usage & $\begin{array}{c}- \\
0,057\end{array}$ & $\begin{array}{c}- \\
1,030\end{array}$ & 0,304 & & & \\
\hline & \begin{tabular}{|l|} 
Virtual \\
Worlds usage
\end{tabular} & 0,256 & 3,901 & 0,000 & & & \\
\hline
\end{tabular}

Regression analysis done with the aim of determining the cause-and-effect relationship between the usage of blog, microblog, social networking, media sharing site, wiki, social marking and labelling site, online communities, podcast, virtual worlds and consumer behavior after purchase in social media was found to be statistically significant $(\mathrm{F}=26,584$; $\mathrm{p}=0,000<0.05$ ). The relationship (the power of explanatories) with the variables the usage of blog, microblog, social networking, media sharing site, wiki, social marking and labelling site, online communities, podcast, virtual worlds with as a determinant of consumer behavior after purchase in social media, was found to be strong $\left(\mathrm{R}^{2}=0,389\right)$. The level of microblog usage by the students increases the level of consumer behavior after purchase in social media $(\beta=0,110)$. The level of social network usage by the students increases the level of consumer behavior after purchase in social media $(\beta=0,153)$. The level of media sharing sites usage by the students increases the level of consumer behavior after purchase in social media $(\beta=0,233)$. The level of wiki usage by the students does not affect the level of consumer behavior after purchase in social media $(\mathrm{p}=0.063>0.05)$. The level of virtual world usage by the students increases the level of consumer behavior after purchase in social media $(\beta=0,256)$.

\section{CONCLUSION AND DISCUSSION}

The majority of the university students participating in the research in Turkey spends maximum 5 hours a week on the internet and social media. In this case, it can be said that the participants' intention to go online is to follow social media. On the other hand, the tool used by the participants to go online is overwhelmingly smart phone. The fact that university students who make up the young part of our society use mobile phones for the internet that deeply affect our lives in the dynamic lifestyle of modern-day, reveals the importance and functionality of smartphones once again.

According to responses to the items about consumer behavior in social media, university students are influenced by social media research during the decision-making phase of purchase behavior and pay particular attention to the comments of individuals who have this product on the product they will purchase, and to the ideas of people whom they know about the product. In other words, university students are researching social media while purchase a product and rely on social media to get ideas and thoughts of people whom they know or not about the product they will purchase.

When we look at the answers given to the items about how much social media tools such as blog, twitter, facebook, google plus, youtube, flickr, slideshare, wikipedia, stumbleupon, reddit, forums, dictionaries, knight online and wow affect the purchase decision, it is seen that students are affected by none of these tools while purchase. It can be argued that other elements other than the social media tools are influential on purchase behavior of university students in the light of the findings. On the other hand, it can be said that the use of social networking, media sharing sites and online communities have a positive effect on university students' pre-purchase consumer behavior. Finally, the use of microblogging, social networking, media sharing sites, online community and virtual worlds have a positive effect on university students' consumer behavior after purchase in social media. In this context, the usage level of social marking and labeling site has a negative effect on the consumers' behavior after purchase in social media.

The suggestions that can be made on the findings are as follows; (I) social media stands out as a heavily used tool by consumers, and the level of consumers' use of social media tools and the level of their influence are parallel to each other. In this context, it is essential that businesses, institutions and all institutional structures exist in the social media environment for marketing activities, (ii) enterprises should organize their social media campaigns taking into account that there is a positive relationship between consumers' behavior before and after purchase; (iii) Companies should share introductory information about products / services, brands and companies in their social media tools, taking into account that consumers conduct research on products / services in their social media tools; (iv) businesses should use social media tools at the point of marketing communication as soon as possible, in line with the fact that consumers indicate that social media is the right place to communicate with consumers.

\section{REFERENCES}

[1] S., Aksoy. (2014). “4077-6502 Sayılı Tüketicinin Korunmas Hakkındaki Kanun Karşılaştırması", Ankara: Ankara Barosu Yayınlart.

[2] K. I., Al-Jeraisy. (2008). “Consumer Behavior: An AnalyticalStudy of TheSaudiFamily's PurchaseDecision". Riyadh: King Fahd National Library Cataloging.

[3] M.E. Babacan, İ. Haşlak and İ. Hira .(2011). "Sosyal Medya ve Arap Baharı", Akademik Incelemeler Dergisi, 6(2), 63-92

[4] S. Barutçu and M. Tomaș (2013). "Sürdürülebilir Sosyal Medya Pazarlaması ve Sosyal Medya Pazarlaması Etkinliğinin Ölçümü”, Internet Uygulamalarl ve Yönetimi Dergisi, 4(1), 5-23.

[5] Z. Battallar and M. Cömert (2015). "Tüketicilerin Tercihlerinde Sosyal Medyadaki Reklamların Etkisi”, Turizm Akademik Dergisi, 2 (1),39-48

[6] J. Comm.(2010). "TwitterPower", America: Wiley Publishing

[7] E. Constantinides and M. Z. Stagno (2011). "Potential of theSocial Media As Instruments of Higher Education Marketing: A SegmentationStudy". Journal of Marketing for Higher Education, 21 (1), 7-24.

[8] V. Çağlıyan, S. A. Hassan, and Z. E. Işıklar (2016). "Üniversite Ögrencilerinin Satın Alma Davranışlarında $\quad$ Sosyal $\quad$ Medya Reklamlarının Etkisi: Selçuk Üniversitesi'nde Bir Araştırma”. Selçuk Üniversitesi Sosyal ve Teknik Araştırmalar Dergisi, (11), 43-56 
[9] Y. Durmaz, R Bahar. and M. Kurtlar. (2011). "Kișisel Faktörlerin Tüketici Satın Alma Davranışlarına Etkisi Üzerine Bir Araştırma”, Akademik Yaklaşımlar Dergisi, 2(1), 114-133

[10] E. Erdoğmuş and M. Çiçek (2012). "TheImpactof Social Media Marketing on Brand Loyalty", Procedia - Socialand Behavioral Sciences, 58, $1353-1360$.

[11] S. Gümüş and M. Özel (2013). "Üniversite Öğrencilerinin Dijital Pazarlama ve Sosyal Medya Kullanımı", Trakya Üniversitesi Iktisadi ve Idari Bilimler Fakültesi E-Dergi, 2(2), 1-25

[12] S. Gunelius (2011). "30 Minute Social Media Marketing”. New York: McGrawHil

[13] B. Hüseyinoğlu. (2009). "Tüketici Tarafindan Yaratılan Medya Ortamında Ağızdan Ağıza Pazarlama ve Bir Uygulama”, Yayınlanmamış Yüksek Lisans Tezi, Yıldız Teknik Üniversitesi, Sosyal Bilimler Enstitüsü, İstanbul.

[14] E. Karabacak.(1993). "Medyanın Tüketici Davranıșları Üzerindeki Etkisi ve Pazarlama Yönetimi Açısından Önemi”, Yayınlanmamış Yüksek Lisans Tezi, Selçuk Üniversitesi, Sosyal Bilimler Enstitüsü, Konya

[15] F. R. Kardes, M. L., Cronley \& T. W. Cline. (2008). "Consumer Behaviour". Mason, $\mathrm{OH}$ : South-Western Cengage Learning.

[16] Y. Köksal and Ş. Özdemir. (2013). "Bir İletişim Aracı Olarak Sosyal Medya'nın Tutundurma Karması İçerisindeki Yeri Üzerine Bir İnceleme", Süleyman Demirel Üniversitesi İktisadi ve İdari Bilimler Fakültesi Dergisi, 1(18), 323-337.

[17] S.M. İslek. (2012) "Sosyal Medyanın Tüketici Davranışlarına Etkileri: Türkiye'deki Sosyal Medya Kullanıcıları Üzerine Bir Araştırma”, Yayınlanmamış Yüksek Lisans Tezi, Karamanoğlu Mehmetbey Üniversitesi, Sosyal Bilimler Enstitüsü, Karaman

[18] Z. İyiler (2009). "Elektronik Ticaret Ve Pazarlama İhracatta İnternet Zamanı": 1, Ankara: DTP.

[19] N. Karasar (2009). "Bilimsel Araştırma Yöntemi”. 2. Baskı. Ankara: Nobel Yayınları.

[20] A. Mayfield (2008). "What is Social Media, iCrossing", e-kitap, http://www.icrossing.co.uk/fileadmin/uploads/eBooks/What is Socia 1 Media iCrossing ebook.pdf, ErisimTarih: 10.04.2017.

[21] OECD. (2007). "Participative Web and User-Created Content Web 2.0.Wikis and Social Networking". Paris: OECD.

[22] E. Örücü and S. Tavşancı (2001). "G1da Ürünlerinde Tüketicinin Satın Alma Eğilimini Etkileyen Faktörler ve Ambalajlama”, $\quad$ Muğla Üniversitesi SBE Dergisi, 3(1), 1-13.

[23] H. Tercan (2016). “Tüketici Davranışları Açısından Reklamın Rolü: Özel Okul Reklamlarına Yönelik Tüketici Tutumlarına Yönelik Bir Araştırma”, Yayınlanmamıș Yüksek Lisans Tezi, Marmara Üniversitesi, Sosyal Bilimler Enstitüsü, İstanbul.

[24] Z. Vural and M. Bat. (2010). "Yeni Bir İletișim Ortamı Olarak Sosyal Medya: Ege Üniversitesi İletişim Fakültesine Yönelik Bir Araştırma”, Journal of Yasar University, 20(5), 3348-3382

[25] X. Wang, C. Yu and Y. Wei. (2012), Social Media Peer Communication and Impacts on Purchase Intentions: A Consumer Socialization Framework. Journal of Interactive Marketing, 26(4), 198-208. doi:10.1016/j.intmar.2011.11.004

[26] Zarella, D. (2010). Thesocial Media Marketing Book. Sebastopol, Kanada: O'Reilly.

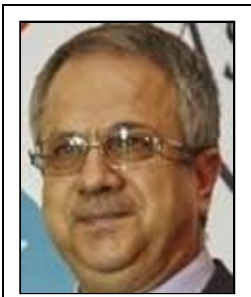

Yakup Durmaz: License; Anadolu University Department of Economics

Master: Kahraman Maraş Sütçü İmam University, Business Administration Department,

PhD: İnönü University Marketing Department.

\begin{tabular}{|c|l|}
\hline $\begin{array}{c}\text { Author's formal } \\
\text { photo }\end{array}$ & $\begin{array}{l}\text { Elif Uysal Alagöz: Graduated from Master of } \\
\text { Business Administration at Hasan Kalyoncu } \\
\text { University }\end{array}$ \\
\hline
\end{tabular}

